\title{
Serum Lipoprotein Disc Electrophoretic Patterns and Ischemic Heart Disease*
}

\author{
By
}

\author{
Mitsuo Wada, Makoto Komoda and Jun'ichi Mise ${ }^{* *}$
}

\section{Introduction}

Owing to the advances in lipid and lipoprotein chemistries in the past few decades, translation of hyperlipidemia into hyperlipoproteinemia which is the most adequate expression of hyperlipidemic state in living animals become possible. Fredrickson and his associates $^{1)}$ have made successfully an integrated approach to various forms of familial hyperlipoproteinemia from clinical and genetic view points and had proposed the five phenotypes of familial hyperlipoproteinemia. The phenotyping system was modified later by WHO committee ${ }^{2)}$ and extended to nonfamilial hyperlipoproteinemia. In this modification, type II phenotype was subdivided into two types; II-A and II-B.

Early in 1957, Besterman ${ }^{3)}$ found out high occurrence of abnormal lipoprotein (pre-beta lipoprotein in paper electrophoresis) among ischemic heart patients. Many other reports including our previous work ${ }^{4}$ ) have eonfirmed his finding. Falsetti et al. ${ }^{5)}$ are probably the first who studied hyperlipoproteinemia in angiographically established coronary atherosclerotic patients. In their study, 17 of $27(62.9 \%)$ patients showed hyperlipoproteinemia ; 13 type II (not subdivided) patients and 4 type IV patients. The finding was reproducible as the number of the patients was increased to $70^{6}$ ). Heinle et al. ${ }^{7)}$ reported that 68 of $126(54 \%)$ patients with angiographically established coronary atherosclerosis showed hyperlipoproteinemia. In cases with angiographically proved normal coronary arteries, occurrence of hyperlipoproteinemia was only $11 \%$ (7 of 66 subjects). Thirty six and 32 of 68 patients with lipoprotein abnormalities were type II and type IV, respectively. These studies strongly suggest that lipoprotein analysis would be one of the most effective means to detect atherosclerosis susceptible individuals at the earliest stage of developing coronary artery lesion.

Conventional diagnostic way of phenotyping hyperlipoproteinemia is based principally on paper electrophoretic analysis of serum lipoproteins aided by serum lipid determinations, physical findings if any, and some other laboratory findings. Lipoprotein ana: lysis, worked usually with paper $^{8)}$, agarose ${ }^{9)}$, or synthetic membrane ${ }^{10)}$. electrophoresis, plays a key role and is indispensable for correct identification of the phenotypes. However, limited resolution of lipoproteins which is inherent to the conventional electrophoretic methods has impeded extensive application of the phenotyping system. For example, differentiation of electrophoretic pattern of phenotype III from those of phenotype IV or II-B is not convincing frequently even with electrophorogram of the best quality, and correct differentiation of the subjects with phenotype III from others has been impossible practically.

The need for more sophisticated method of lipoprotein analysis than conventional methods has been obvious for the past years. Several methods have been explored to meet the need. Among them, poly; acrylamide gel (PAG) disc type electrophoresis ${ }^{11,12)}$

\footnotetext{
* 血清リポ蛋白質ディスク電気泳動像と虚血性心疾患.

** 和田光夫 - 萀田 信 - 三瀬淳一, 山口大学医学部第 2 内科学教室.
} 
s the latest addition. PAG disc system formulated by us $^{13,14)}$ proved its practical workability in most of common clinical laboratories. Reliability of the method has been proved:further with PAG block electrophoresis ${ }^{15)}$ combined either with immunological or lipid chemical techniques ${ }^{16)}$.

The objective of this study is to investigate hyperlipoproteinemia in ischemic heart disease with PAG disc electrophoresis added to the other conventional analytical methods. The method is effective in identifying hyperlipoproteinemia of modest to moderate degree which is encountered frequently in ischemic heart patients as well as in identifying evident hyperlipoproteinemia of familial or sporadic hyperlipoproteinemia.

\section{Patients and Methods}

Four hundred and twenty eight patients who showed any clinical signs or symptoms suggestive of ischemic heart disease were studied. Only two of them had physical and laboratory findings consistent with sporadic phenotype II and IV hyperlipoproteinemia. As a control group of lipoprotein study, 403 subjects in apparent health judged by more than two successive examinations including resting ECGs, chest $\mathrm{X}$-rays and routine office laboratory tests collaborated with this study. Patients with lipid or lipoprotein disorders secondary to ohter diseases than atherosclerotic cardiovascular disease were not included in this study.

Clinical diagnosis of ischemic heart disease was established by reviewing present status, documented clinical histories, resting or exercise ECGs as many as available, chest $\mathrm{X}$-rays of posteroanterior or multiple projections, blood chemistries and all other laboratory data of the patients. Diagnostic criteria set by WHO (ischemic heart disease) ${ }^{17}$, The Ministry of Education of Japan (coronary atherosclerosis) ${ }^{18)}$, The Ministry of Health and Welfare of Japan (hypertension and ischemic heart disease ${ }^{19}$ ) and Minnesota Code (resting and exercise ECG) ${ }^{20}$ ) were consulted to establish presence or absence of ischemic heart disease.

Blood samples were obtained more than 14 hours after the last meal. Serum was used for lipid and lipoprotein analysis. Determination of serum total cholesterol $^{21)}$ and triglyceride ${ }^{22)}$ was made in all patients. Serum phospholipids ${ }^{23}$ ) were determined in some of the patients. The report recently published by the study group of The Ministry of Education of Japan on age level of serum total cholesterol and triglyceride in Japanese male and female population ${ }^{24}$ ) was consulted in evaluating serum lipid levels of the patients and control subjects.

Paper electrophoresis of serum lipoproteins was performed following the procedures by Lees et al. ${ }^{8)}$ with modification ${ }^{25)}$. Whatman No.3 MM filter paper was employed. Bovine serum albumin (Fraction V, Armour and Co., U.S. A.) and disodium EDTA were added ( $1 \%$ and $0.001 \mathrm{M}$, respectively) to sodium barbiturate-hydrochloric acid buffer system, $\mathrm{pH}$ 8.6. Staining of lipoproteins on filter paper followed the method of Jencks et al. ${ }^{26)}$

PAG disc electrophoresis of serum lipoproteins followed the method reported previously from our laboratory ${ }^{13)}$. Acrylamide concentration of separating gel was modified to $3.70 \%$ from the original $3.75 \%$ in this study. Reagents were obtained from the same sources as described in the previous report ${ }^{13)}$ except lipid dye. Eastman's Sudan Black B (Eastman Kodak Co., U. S. A.) was employed in this study because of better stainability than that we had used.

\section{Results}

Reviewing lipoprotein PAG disc electrophorograms of all the subjects in this study and of approximately 2480 clinical subjects we have analysed for the past 3.5 years, the authors conceived that lipoprotein PAG disc patterns could be classified into several basic patterns. In this report, six basic lipoprotein patterns were defined empirically. They are expressed as b, bp, B, $\mathrm{Pb}$ and $\mathrm{PB}$ patterns. Electrophoretic characters of these basic lipoprotein patterns, on which identification of basic lipoprotein patterns has been made, are describable as follows (Fig. 1); b pattern : Sudan Black B stained density of $\alpha$ and $\beta$ lipoproteins are not increased and defined as normal. Mobility of $\beta$ lipoprotein is also defined as nomal. Pre- $\beta$ lipoprotein is not detectable. Chylomicrons are not detectable.

bp pattern : the pattern is essentially the same as b 
pattern except modestly detectable pre- $\beta$ lipoprotein and slightly decreased $\alpha$ lipoprotein.

B pattern : dense and wide $\beta$ lipoprotein band is characteristic to this pattern. Mobility of $\beta$ lipoprotein is slow as compared to that of $b$ or bp patterns. Alpha lipoprotein is normal usually.

Bp pattern : moderate pre- $\beta$ lipoprotein band coexists with $\beta$ lipoprotein of $\mathrm{B}$ pattern. Alpha lipoprotein is normal or increased as compared to $\mathrm{b}$ pattern.

$\mathrm{Pb}$ pattern : markedly increased pre- $\beta$ lipoprotein is characteristic to this pattern. Beta lipoprotein is always fast migrating in nature and is obviously decreased as compared with $\beta$ lipoprotein of $b$ or $b p$ patterns. Alpha lipoprotein is markedly decreased as a rule.

PB pattern : marked increase of pre- $\beta$ lipoprotein coexists with increased $\beta$ lipoprotein. Beta lipoprotein band is observed as equal to, or less marked than $\beta$ lipoprotein of $\mathrm{B}$ or $\mathrm{Bp}$ pattern. Mobility of $\beta$ lipoprotein is faster than $B$ pattern but slower than $b$ pattern. Alpha lipoprotein is moderately decreased or normal.

Because of high resolution of PAG electrophoresis, further subdivision of lipoprotein patterns was possible. For example, presence of the midband lipoprotein $^{14)}$ ("Zwischenband"12) or intermediate lipoprotein ${ }^{13)}$ ), or presence of chylomicrons which are clearly detectable with the author's method would permit further subdivision. However, these subdivisions were not employed in this study, but included in any one of the six basic lipoprotein patterns.

Lipoprotein paper electrophorograms of the same patients as presented in Fig. 1 are shown in Fig. 2 (identical sera). It is obvious that PAG disc electrophorograms are consistent principally with paper electrophorograms and provide us with finer details of lipoprotein profiles than paper electrophorograms.

Serum lipid levels of six groups of 831 subjects divided by their lipoprotein pattern are compared in Table 1. As shown, total cholesterol level difference between $\mathrm{bp}$ and $\mathrm{Bp}$ patterns and between $\mathrm{Bp}$ and $\mathrm{Pb}$ patterns were statistically significant (Student " $t$ " test), but difference between $\mathrm{Pb}$ and $\mathrm{PB}$ was not significant. Triglyceride level difference between bp and $b, B$

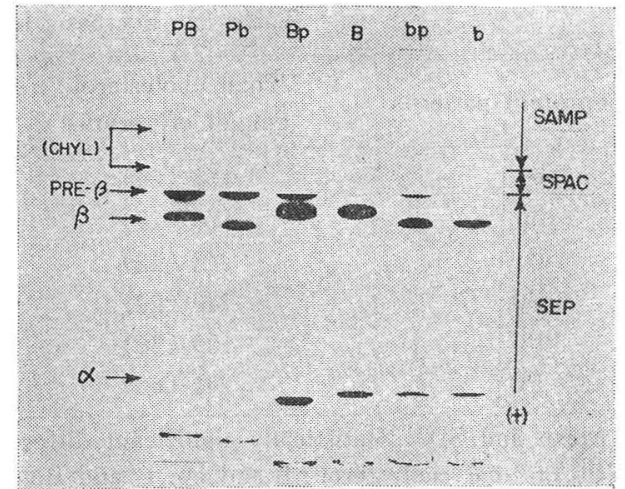

Fig. 1. Polyacrylamide gel disc electrophorograms of six basic lipoprotein patterns which are most frequently encountered among atherosclerotic cardiovascular patients.

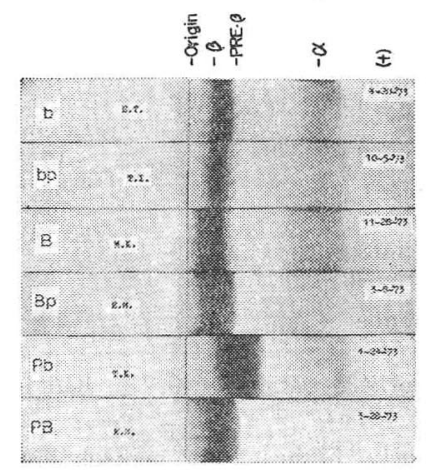

Fig. 2. Paper electrophorograms of the patients identical to those shown in the previous figure.

and $\mathrm{Bp}$, and $\mathrm{Bp}$ and $\mathrm{Pb}$ were significant. There were observed no significant differences among lipoprotein patterns regarding phospholipid level.

In the Table 2 , occurrences of lipoprotein patterns in cardiovascular patients and in apparently healthy control subjects are compared. Incidences of ischemic heart disease in patient group are also shown. Occurrences of $b$ and $b p$ patterns in control group were $47.2 \%$ and $30.3 \%$, respectively ; approximately $77 \%$ of the control subjects had these lipoprotein patterns, while it was approximately $39 \%$ in the patient group. Occurrences of $\mathrm{B}$ pattern in patient group and control group was almost the same occupying $8.9 \%$ and $8.2 \%$, respectively. Occurrences of $\mathrm{Bp}$ pattern in patient group and control group were $12 \%$ and $7 \%$ approximately. Occurrence of $\mathrm{Pb}$ pattern in the patient group 
Table 1. Six basic lipoprotein patterns and serum lipids.

\begin{tabular}{c|c|c|c}
\hline \hline Lipoprotein patterns & $\begin{array}{c}\text { Total cholesterol } \\
\text { (mg/dl of serum) }\end{array}$ & $\begin{array}{c}\text { Triglyceride } \\
\text { (mg/dl of serum) }\end{array}$ & $\begin{array}{c}\text { Phospholipids } \\
\text { (mg/dl of serum) }\end{array}$ \\
\hline $\mathrm{b}$ & $168(24)$ & $80(16)$ & $175(38)$ \\
$\mathrm{bp}$ & $176(25)$ & $116(24)$ & $185(41)$ \\
$\mathrm{B}$ & $242(42)$ & $97(31)$ & $236(40)$ \\
$\mathrm{Bp}$ & $240(29)$ & $133(32)$ & $245(31)$ \\
$\mathrm{Pb}$ & $183(36)$ & $205(95)$ & $214(43)$ \\
$\mathrm{PB}$ & $241(43)$ & $218(75)$ & $221(49)$ \\
\hline
\end{tabular}

Mean and SD. Statistically significant differences $(p<0.05)$ were observed between; bp and $B p, B p$ and $\mathrm{Pb}$ of total cholesterol; $\mathrm{b}$ and $\mathrm{bp}, \mathrm{B}$ and $\mathrm{Bp}, \mathrm{Bp}$ and $\mathrm{Pb}$ of triglyceride, respectively,

Table 2. Occurrences of six basic lipoprotein patterns and incidence of ischemic heart disease.

\begin{tabular}{l|c|c|c|c|c|c}
\hline \hline \multirow{2}{*}{ Population } & \multicolumn{7}{|c}{ Lipoprotein patterns } \\
\cline { 2 - 7 } & $\mathrm{b}$ & $\mathrm{bp}$ & $\mathrm{B}$ & $\mathrm{Bp}$ & $\mathrm{Pb}$ & $\mathrm{PB}$ \\
\hline Cardiovascular \\
patients (n=428) & & & & & & \\
$\quad$ Occurrence (\%) & 16.6 & 22.6 & 8.9 & 12.4 & 31.3 & 8.6 \\
$\quad$ Incidencea (\%) & 25.3 & 29.9 & 64.9 & 60.4 & 42.1 & 40.6 \\
\hline $\begin{array}{l}\text { Healthy control } \\
\text { subjects (n=403) }\end{array}$ & & & & & & \\
Occurrence (\%) & 47.2 & 30.3 & 8.2 & 7.2 & 7.0 & 0.3 \\
\hline
\end{tabular}

a : 174 of 428 patients $(40.7 \%$ ) had ischemic heart disease

were obviously higher than control group; it was approximately $31 \%$ in the patient group and $7 \%$ in the control group. Occurrence of $\mathrm{PB}$ pattern in the patient group was approximately $9 \%$ and it was lower than $1 \%$ in the control group.

Incidences of ischemic heart disease in $\mathrm{B}$ and $\mathrm{Bp}$ patterns were markedly higher than others. Approximately $65 \%$ of the patients with B patterns and $60 \%$ of the patients with Bp pattern were ischemic heart patients. Incidences of ischemic heart disease in $\mathrm{Pb}$ and PB patterns were approximately $42 \%$ and $41 \%$, respectively. Incidences of ischemic heart disease in the patients with $\mathrm{b}$ and $\mathrm{bp}$ patterns were approximately $25 \%$ and $30 \%$, respectively.

An investigation of the relationship between lipoprotein patterns and incidence of ischemic heart disease in decadal age group gave a result suggesting that age factor is implicated in the development of ischemic heart disease associating with lipoprotein pattern. As shown in Table 3, incidence of ischemic heart disease exceeded $50 \%$ at the 7 th decade (61 to 70 years old) in the patients with $\mathrm{b}$ pattern, at the 6 th decade in the patients with bp and PB pattern, at the 5 th decade in the patients with $\mathrm{B}$ or $\mathrm{Pb}$. pattern and at the 4 th decade in the patients with Bp pattern, respectively.

\section{Discussion}

As studied with lipoprotein PAG disc electrophoretic method, six lipoprotein patterns were differentiable as basic variations of serum lipoprotein profile.

Of the six basic lipoprotein patterns, $\mathrm{B}, \mathrm{Bp}$ and $\mathrm{Pb}$ patterns are describable as hyperbeta lipoproteinemia, hyperbeta lipoproteinemia associated with moderate hyperpre-beta lipoproteinemia and hyperpre-beta lipoproteinemia, respectively. Following WHO's definition, they are phenotypes II-A, II-B and IV, respectively, though only two of approximately 830 subjects studied in this work showed physical signs and laboratory findings consistent with sporadic hyperlipoproteinemia 
Table 3. Incidences of ischemic heart disease in decadal age groups of six basic lipoprotein patterns ${ }^{\mathrm{a}}$.

\begin{tabular}{c|c|c|c|c|c|c}
\hline \hline \multirow{2}{*}{$\begin{array}{c}\text { Lipoprotein } \\
\text { pattern }\end{array}$} & \multirow{2}{*}{$\mathrm{N}^{\mathrm{b}}$} & \multicolumn{5}{|c}{ Age group } \\
\cline { 3 - 7 } & & $\sim 40$ & $41 \sim 50$ & $51 \sim 60$ & $61 \sim 70$ & $70 \sim$ \\
\hline $\mathrm{b}$ & 71 & $0^{*}$ & 0.19 & 0.40 & 0.67 & 0.70 \\
$\mathrm{bp}$ & 97 & 0.17 & 0.33 & 0.53 & 0.57 & 0.50 \\
$\mathrm{~B}$ & 37 & 0.22 & 0.67 & 0.67 & 0.83 & 1.00 \\
$\mathrm{Bp}$ & 53 & 0.53 & 0.46 & 0.62 & 0.71 & 0.50 \\
$\mathrm{~Pb}$ & 133 & 0.14 & 0.58 & 0.56 & 0.70 & 1.00 \\
$\mathrm{~PB}$ & 37 & 0.07 & 0.46 & 0.80 & 0.50 & 0.60 \\
\hline
\end{tabular}

a : Incidence in an age group is expressed by dividing number of the patients with ischemic heart disease by total number of the patients in an age group of a lipoprotein pattern. $\mathrm{b}:$ number of the patients.

* : none had ischemic heart disease.

of the classical definition.

The prevalent lipoprotein pattern among the healthy control subjects were $\mathrm{b}$ and bp pattern (approximately $77 \%$ of the subjects). Incidence of ischemic heart disease in the patients with bp pattern was not obviously higher but the earliest possible onset of ischemic heart disease was lower as compared with the patients with $\mathrm{b}$ pattern.

Occurrence of B and Bp patterns were low both in the control subjects and patient group. However, incidences of ischemic heart disease in those who were associated with these lipoprotein patterns were extremely high (more than $60 \%$ ) as compared with others. Incidence of ischemic heart disease in the patients with $\mathrm{Pb}$ pattern was lower than in the patients with $\mathrm{B}$ or $\mathrm{Bp}$ pattern, but occurrence of this pattern in the patient group was high suggesting that total number of the patients with this lipoprotein abnormality and ischemic heart disease are to be estimated as large. These findings are consistent with the studies ${ }^{3,4,6,7)}$ performed by means of paper electrophoretic methods.

PB pattern is a combined hyperbeta and hyperprebeta lipoproteinemia, which is differentiable convincingly with $\mathrm{PAG}$ disc electrophoresis from $\mathrm{Bp}$ or $\mathrm{Pb}$ patterns. From clinical view point, incidence of ischemic heart disease in $\mathrm{PB}$ pattern was lower than in Bp pattern. Estimated age of the earliest possible onset of ischemic heart disease in the patients with PB pattern was higher than in those who with Bp pattern. Therefore, it seems more reasonable to con- sider that PB pattern is an independent lipoprotein pattern from other patterns, especially from $\mathrm{Bp}$ or $\mathrm{Pb}$ patterns. The most adequate category to which $\mathrm{PB}$ pattern belongs seems to be "the sixth phenotype" 27) or "the combined hyperlipoproteinemia ${ }^{28)}$. In this case, phenotype VI is not the sixth but should be the seventh phenotype, because phenotype II-B of WHO definition $^{2)}$ is identifiable as Bp pattern with PAG disc electrophoresis.

\section{Summary}

Serum lipoprotein polyacryamide gel disc electrophoresis aided by paper electrophoresis was proved to be effective to detect and identify convincingly modest to moderate hyperlipoproteinemias which are frequently encountered in atherosclerotic cardiovascular clinic. Hyperbeta lipoproteinemia with moderate increase of pre- $\beta$ lipoprotein ( $\mathrm{Bp}$ pattern, type II-B of WHO definition) showed closest association with ischemic heart disease. Premature development of ischemic heart disease in the patients with this lipoprotein pattern was evident. Hyperbeta lipoproteinemia (B pattern, type II-A of WHO definition) showed also close association with high incidence and premature development of ischemic heart disease. Hyperprebeta lipoproteinemia ( $\mathrm{Pb}$ pattern, type $\mathrm{IV}$ of WHO definition) occurred most frequently among atherosclerotic cardiovascular patients, though incidence of ischemic heart disease was lower than those with $\mathrm{Bp}$ or B patterns. The mixed hyperlipoproteinemia (PB pattern, the sixth phenotype) which is identifiable 
most adequately with PAG disc method showed the incidence of ischemic heart disease comparable to those in $\mathrm{Pb}$ pattern and the occurrence comparable to those in $\mathrm{B}$ pattern. The sixth phenotype should be the seventh phenotype because phenotype II-B (Bp pattern) is clearly differentiable from the mixed hyperlipoproteinemia (PB pattern).

\section{要約}

動脈硬化性病変を背景として生じる虚血性心疾患は, 血清脂質ならびに血清リポ蛋白質の異常と密接に関連す る. 本研究の目的は古典的な血清りポ蛋白質汇紙電気泳 動法に高い電気泳動的分離能を有するポリアクリルアミ ドゲル・ディスク電気泳動法を加えた分析を行ない，虚 血性心疾患に护ける血清リポ蛋白質の異常を一層鮮明に 捉えようとするものである。

対象は心循環器系疾患に関係した愁訴を以て受診もし くは入院をした患者を中心とし，ほぼ同数の健常者が含 まれている。全例につき理学所見, 一般臨床生化学的検 査, 胸部 X線検査, 心電図検查, 脂質化学的検査などを 実施した。血清りポ蛋白質沪紙ならびにディスク電気泳 動法は著者らの既報した方法に従って実施した。

対象例の血清りポ蛋白質ディスク電気泳動像は 6 種の 基本的電気泳動像 ( $\mathrm{b}, \mathrm{bp}, \mathrm{B}, \mathrm{Bp}, \mathrm{Pb}, \mathrm{PB}$ と仮称さ れた）に分類することができた。これらはそれぞれにあ る程度特徵的な脂質化学的性質を示していた. 臨床像と の関連では高 Bリポ蛋白質血症状態を反映する Bあるい は Bp の像が集団に护ける出現頻度は比較的低いが，虚 血性心疾患の検出率は著しく高く $(60 \sim 65 \%)$, 注目され た.高プレ・ $\beta$ ポ蛋白質血症の状態を示す $\mathrm{Pb}$ の像は， 虚血性心疾患の検出率は比較的低い（42\%）肪，患者集 団に打将出現頻度が対照集団に比べて著しく高い点が 注目された。 PB 型は最近提唱されるに至っている第 $\mathrm{VI}$ のフェノタイプもしくは混合型高リポ蛋白質血症に相当 するものと考えられるがディスク法によって適確に診断 され得た. 出現頻度はBあるいは Bp に近く, 虚血性心 疾患の検出頻度は $\mathrm{Pb}$ のそれに近い率を示した。本研究 の結果からポリアクリルアミドゲル電気泳動法による血 清リポ蛋白質の分析は, 虚血性心疾患患者に护汗る異常 の検出に有効であると結論された。

\section{References}

1) Fredrickson, D. S., Levy, R. I., and Lees, R. S. : New Engl. J. Med. 276, 34, 94, 148, 215 and 273 (1967).

2) Beaumont, J. L., Carlson, L. A., Cooper, G. R.,
Feifar, Z., Fredrickson, D. S. and Strasser, T.: Bull. Wld. Hlth. Org. 42, 891 (1970).

3) Besterman, E. M. M. : Brit. Heart J. 19, 503 (1957).

4) Wada, M. : The Saishinigaku 24, 2326(1969).

5) Falsetti, H. L., Schnatz, J. D., Green, D. C. and Bunnel, I. L. : Circulation 37, 184(1968).

6) Falsetti, H. L., Schnatz, J. D., Green, D. C, and Bunnel, I. L. : Chest 58, 111 (1970).

7) Heinle, R. A., Levy, R. I., Fredrickson, D. S. and Gorlin, R. : Amer. J. Cardiol. 24, 178 (1969).

8) Lees, R. S. and Hatch, F. T. : J. Lab. \& Clin. Med. 61, 518 (1963).

9) Noble, R. P. : J. Lipid Res. 9, 693 (1972).

10) Chin, H. P. and Blankenhorn, D. H. : Clin. Chim. Acta 20, 305 (1968).

11) Narayan, R. A., Creinin, H. L. and Kummerow, F.A. : J. Lipid Res. 7, 151 (1966).

12) Wollenweber, J. und Kohlke, W. : Clin. Chim. Acta 29, 411 (1970).

13) Wada, M. and Mise, J. : Jap. Circul. J. 36, 335 (1972).

14) Naito, H. K., Wada, M., Ehrhart, L. A. and Lewis, L. A. : Clin. Chem. 19, 228 (1973).

15) Wada, M., Naito, H. K., Ehrhart, L. A. and Lewis, L. A. : Clin. Chem. 19, 235 (1973).

16) Wada, M., Minamisono, T., Akamatsu, A., Wada, K., Morita, T., Fujii, $\mathrm{H}$ and Mise, J.: Jap. J. Atheroscler. (Domyakukoka) 2, 181 (1974).

17) Expert commitee on arterial hypertension and ischemic heart disease (Chairman, Horace Smirk) : Wld. Hlth. Org. Tech. Rep. Ser. 231 (1962):

18) Research commitee on hypertension and heart disease (Chairman, Okinaka, S.) : Jap. Med. J. (Ijishimpo) No. 2204, 8 (1966).

19) Research commitee on atherosclerosis (Chairman, Okinaka, S.) Ann. Rep. Co-op. Res. Minist. Educ. Vol. 12 (1961).

20) Blackburn, H., Keys, A, Simonson, E., Rautaharju, P. and Punsar, S. : Circul. 21, 1160 (1960).

21) Zurkowski, P. : Clin. Chem. 101, 451 (1964).

22) Fletcher, M. J. : Clin. Chim. Acta 22, 393 (1968).

23) Hoeflmayer, J. und Fried, R. : Medizin u. Ernaehr. 7, 9 (1966).

24) Research commitee on hyperlipidemia in Japan (Chairman, Ooshima, K.) : Jap. J. Atheroscler. (Domyakukoka) 1, 101 (1973).

25) Wada, M. : Jap. J. Clin. Path. (Rinshobyori) 17, 169 (1969).

26) Jencks, W. P. and Durrum, E. L. : J. Clin. Invest. 34, 1437 (1955).

27) Brown, H. L., Lewis, L. A. and Page I. H. : Atherosclerosis 17, 181 (1973).

28) Rose, H. G., Kranz, P, Weinstock, M., Juliano, J. and Haft, J. I. : Atherosclerosis 20, 51(1974). 